\title{
Input Factors to Sustainable Development of Coffee Production in the Dak Lak Province
}

\author{
Hoang Tuan Minh1, Doan Thi Nhu Trang2, Jiancheng Chen ${ }^{3 *}$ \\ ${ }^{1}$ Beijing Forestry University, Beijing, China \\ ${ }^{2}$ University of Science and Technology Beijing, Beijing, China \\ ${ }^{3}$ Economics and Management School, Beijing Forestry University, Beijing, China \\ Email: *1850908663@qq.com
}

How to cite this paper: Minh, H.T., Trang, D.T.N. and Chen, J.C. (2016) Input Factors to Sustainable Development of Coffee Production in the Dak Lak Province. Open Access Library Journal, 3: e3187.

http://dx.doi.org/10.4236/oalib.1103187

Received: November 2, 2016

Accepted: November 29, 2016

Published: December 2, 2016

Copyright $\odot 2016$ by authors and Open Access Library Inc.

This work is licensed under the Creative Commons Attribution International

License (CC BY 4.0)

http://creativecommons.org/licenses/by/4.0/

\begin{abstract}
Coffee has brought income for many households and significantly contributes to annual GDP growth of the Dak Lak province. The majority of households have said that water sources, soil quality, coffee caring techniques, capital, and cultivation experience are important for the sustainable development of coffee production [Table A1]. We used linear function and Cobb-Douglas functional form to analyze the factors affecting the sustainable development of coffee. The production has shown that capital, labor, and land are important factors contributing to improving coffee productivity. The impact assessments of certain factors, such as agricultural equipment, knowledge of farmers, and the investment of capital, are essential for researching sustainable coffee development. Furthermore, the research results will provide some useful information for those working in the agricultural sector management, the agricultural extension center, and the coffee-growing households in investing, planning and development of Dak Lak coffee to reach high yielding, stable and more efficient in the future.
\end{abstract}

\section{Subject Areas}

Statistics and Econometrics

Keywords

Input Factors, Sustainable Development, Coffee Production, Dak Lak

\section{Introduction}

More than $64 \%$ of Dak Lak province's population over 1 million farmers grow coffee as their primary source of income. The coffee industry also generates more than 500,000 
jobs, in addition to farmers, and the region produces more than 1.5 million tons of it annually, contributing to around 40 percent of the nation's production. Coffee from the province was shipped to 60 countries worldwide with an export value of US $\$ 650$ million and accounted for $90 \%$ of the total exports of the province. Today Dak Lak coffee benefits not only from its brand name identification but also from its geographical identification and the region is generally considered the coffee metropolis of Vietnam.

Dak Lak is the earliest province about coffee cultivation, and has more experiences, considerable planting techniques, so yields reached the highest in the Central Highlands. However, the cultivation of coffee in this province presents several shortcomings. These include the high number of inexperienced farmers, low intensive investment levels, poor production levels, as well as scientific and technical applications that limit productivity, and contribute to unstable quality and poor crop efficiency. Productivity of Dak Lak coffee is high but unstable. In recent years when input prices increased sharply, especially in the years 2009-2013, the price of fertilizer and labor had increased $25 \%-30 \%$ over the year before. Coffee prices also fluctuated depending on the price of the world's coffee. Therefore, there were periods of time when input prices rose sharply, but coffee prices fell. As a result, coffee growers lost money and could not afford to invest. Coffee plantations were thus unlikely to recover and get high yields during the next season [1].

Besides, more than $85 \%$ of Dak Lak coffee area belongs to the people (the average household coffee area fluctuate from 0.4 hectares to $2 \mathrm{ha}$ ), only about $15 \%$ of the area of the company, and farm. Therefore, production of Dak Lak coffee production is still small and scattered. Farmers mainly use random cultivation techniques which contributed to low product quality and poor competitiveness in the market.

\section{Research Methodology}

To analyze and assess the influence of the inputs to the development of sustainable coffee, within this study, we studied only limited effects of the inputs to the economic effects of Dak Lak Province's coffee. Coffee productivity and coffee production is the measurement of coffee economic effectiveness. Resulting from coffee production business in 2015 (as a linear function and Cobb-douglas functional form).

(1) Cobb-Douglas production function used to study the benefits of scale. The goal of this model to study the benefits from coffee production and trading of households depend on the volume of investment of inputs. General model is as follows:

$$
Y=a X_{1}^{b_{1}} X_{2}^{b_{2}} X_{3}^{b_{3}} \mathrm{e}^{\alpha_{1} D_{1}+\alpha_{2} D_{2}+\alpha_{3} D_{3}+\alpha_{4} D_{4}+\alpha_{5} D_{5}}
$$

(2) The linear function used to study the marginal productivity of the inputs. The goal of this model to study the marginal influence of the input variables on the coffee productivity of households. General model as follows:

$$
Y=a+b_{1} X_{1}+b_{2} X_{2}+b_{3} X_{3}+\alpha_{1} D_{1}+\alpha_{2} D_{2}+\alpha_{3} D_{3}+\alpha_{4} D_{4}+\alpha_{5} D_{5}
$$

$>Y$ (dependent variable): Production (model 1), productivity (model 2) coffee of household in years.

$>$ a: Freedom coefficient of the regression model. 
$>b 1, b 2, b 3$ : the elastic coefficient of the dependent variable to the independent variables (model 1); the marginal productivity of input variables (model 2). The coefficients were estimated by regression methods.

$>\alpha 1, \alpha 2, \alpha 3, \alpha 4, \alpha 5$ : The parameters of qualitative variables.

$>X 1, X 2, X 3$ : respectively independent variables, the total area of the coffee business for coffee production and total labor of household (model 1); Coffee area of the household, the production of capital and labor on average hectare coffee business (model 2).

> D1,D2,D3,D4,D5: respectively qualitative variables, planting windbreaks, soil erosion control measures, participate in the training of agricultural extension, fertilization methods, irrigation methods [2].

Data is from a survey for 500 households in 30 communes of 08 districts and towns: CuKuin district, Krong Ana district, Lak district, Krong Bong district, CuM'gar district, Buon Ho town, Krong Buk district and Krong Pak district (Dak Lak province).

\section{Results of Research}

\subsection{Statistical Analysis Describes the Factors Affecting the Development of Sustainable Coffee}

\subsubsection{The Impact of Fertilization Methods and Water for Coffee}

According to the Institute of Agricultural and Forestry Engineering Highlands (1999) [3], it is recommended for Dak Lak province and according to the author's analysis combined with the experience of experts in coffee, weather, climate, rainfall of Dak Lak province, the fertilizing, watering coffee tree during business under the following is considered reasonable: NPK: 2 to 3.5 tons/ha/year; organic fertilizers: 2 to 3.5 tons/ha/year; water: 03 times/year, $350-550 \mathrm{~m}^{3} /$ ha/batch.

Through the survey (Table A1) showed that 151 (30.8\%) households used rational fertilization, 346 (69.2\%) households put down unreasonable fertilization, it means fertilization does not enough doses or excessive fertilizer lead to pollution and waste and higher costs. Survey results showed that the majority of households are not sufficient dose fertilizers, NPK at least, this is sort of the biggest influences on productivity of coffee (Institute of Agricultural and Forestry Science Highlands, 1999). Since then, yields are affected, not achieved as expected. Only 81 (16.2\%) households have watering reasonably, remaining 419 households (83.8\%) are inappropriate irrigation. The watering of the farmers depend on the rainy season arrives sooner or later, if the rainy season coming soon, households reduce watering and reduce the amount of water in each time. Survey results showed that the majority of households do not irrigate enough water per year for irrigation, even not enough three times per year. It also influences the bloom and harvest coffee production.

Also from the survey results, the survey are summarized in Table A1 shows that households are evaluating the role of water for coffee is very high (average 1.49 points). That suggests, the role and importance of water for the coffee is great. Ability to provide irrigation water for coffee is not abundant. It should use water sensibly. It also avoid to exploit water resources indiscriminately, there is no plan leads to a lack of wa- 
ter in the future. Most households interviewed replied that water sources will reduce in follow years. Only 3 households out of 500 households responded that water tends to increase in the future. This suggests that, if there is no planning for new coffee plantings reasonably, exploiting soils spontaneously and the use of water resources is not rational, exploiting a widespread, indiscriminately leads to exhaustion coffee irrigation water in the future (especially groundwater resources) [4] [5].

\subsubsection{Household Evaluation of the Level of Importance of Some Elements Related to Coffee Production}

The survey in Table A3 shows the evaluation of the role of the inputs factors for coffee production and business are the average achieved greater than 2, in which the experimental factors, coffee production techniques, capital scale and quality of soil are important above. The area scale was also assessed is relatively important. Other factors also inadequate.

\subsection{Analysis of Results and Economic Effects of the Coffee Trees with Households in Each Locality}

Data compiled from Table A4 shows that the average yield of 545.66 ha coffee reached 2.54 tons/ha. Overall, the region has favorable natural conditions as Cukuin, CuM'gar, Krong Buk, Krong Pak have high yield. Other regions, especially Krong Bong and Lak district got the lowest yields in the districts and towns surveyed. The rate of yield area of over 3 tons accounted for the relatively high (62.8\%). Meanwhile, the area was less than 1.5 tons/ha accounted for only $10.21 \%$. This proves Dak Lak coffee productivity is relatively high in general [6].

Data compiled from Table A2 shows that households achieved the results of the coffee business and production rather high. GO average of 1 ha of coffee business reached 62.03 million, VA reached 41.56 million/ha and MI reached 32.72 million/ha. There are 2 districts out of 8 districts, Lak and Krong Bong had the results of coffee production business acquired on 1 ha lower than the rest. These districts are generally in difficult natural conditions for the cultivation of perennial crops, especially coffee. These are lowlands, frequent floods every year, and sandy soil is essential. Therefore, these districts are only suitable for annual crops [7].

VA/IC by 2.03 , meaning every 1 million investment intermediary costs will gain an average of 2.03 million of value added from the production and trading of coffee. MI/IC by 1.6, meaning every 1 million investment intermediary costs will gain an average of 1.6 million mixed income. Overall, the business efficiency of households was relatively high status, Krong Buk, CuM'gar and CuKuin is higher overall efficiency at all. Because these areas are generally favorable natural conditions for growing coffee more. Besides, experience, technique and care from both dominant than other regions [8].

\subsection{Regression Model Results}

\subsubsection{For Coffee Production of Household}

$$
\mathrm{R}=0.857911 ; \mathrm{R}^{2}=0.736012
$$


Coefficient $\mathrm{R}^{2}=0.736012$, model indicates the independent variables explained $73.6012 \%$ change in the dependent variable is the production of coffee.

Results in the Table 1 showed that, with 2 parameters with 2 variable watering method and planting windbreak trees is not significant in terms of statistics. This suggests that, no basis for concluding that a reasonable watering and planting windbreak trees will bring more efficient than watering unreasonable and not planting windbreak trees. The parameters of the remaining variables are statistically significant.

\section{The meaning of the parameters:}

Table 1 shows that parameters of coffee harvest area equal to 0.3422 is the elasticity of output with coffee harvest area, said in the case of other factors in the model unchanged, while land area increased $1 \%$, the yield increased by $0.3422 \%$.

Table 1 shows that parameters of production cost by 0.2868 is the elasticity of output to capital of coffee business, said in the case of other factors in the model constant, while increasing the size of its capital to $1 \%$, the yield increased by $0.2868 \%$.

Table 1 shows that parameters of labor by 0.7299 is the elasticity of output with household labor, said in the case of other factors in the model does not change, when labor increased $1 \%$, the yield increased by $0.7299 \%$.

Total of three parameters coffee harvest area, production capital and labor, with $0.342+0.287+0.750=1.379$. This shows that the regression model increases production with size. At the present time, if the household increases size and the area, capital and labor, the production efficiency will increase the coffee business [9].

Parameters of fertilizing method by 0.0787 shows that reasonable fertilizing will increase coffee production by 0.082 times $\left(e^{0.0787}-1\right)$ versus unreasonable fertilization.

Parameters of agricultural extension by 0.1241 , said households participate agricultural extension work will make coffee production increase by 0.132 times $\left(e^{0.1241}-1\right)$ than households not taking part in the extension.

Parameters of preventing soil erosion by 0.0593 , said that households have used the anti-erosion measures would be increased coffee production by 0,061 times $\left(e^{0.0593}-1\right)$ than households not using measures anti-erosion measures.

Table 1. Regression results table (Cobb-Douglas modeled convert Ln-Ln).

\begin{tabular}{|c|c|c|c|c|}
\hline Order & Variable & Intercept & t Stat & $P$-value \\
\hline 1 & Intercept of freedom & $-4.5713^{* * *}$ & -8.362 & 0.0000 \\
\hline 2 & Coffee production area (ha) & $0.3422^{* * *}$ & 7.166 & 0.0000 \\
\hline 3 & Capital for coffee production (mil.dong) & $0.2868^{* * *}$ & 9.158 & 0.0000 \\
\hline 4 & Labor (man-day) & $0.7499^{* * *}$ & 6.079 & 0.0000 \\
\hline 5 & Irrigation methods (1-suitable; 0 -unsuitable) & -0.0007 & -1.106 & 0.2712 \\
\hline 6 & Fertilizer application(1-suitable; 0-unsuitable) & $0.0787^{\star * *}$ & 2.183 & 0.0295 \\
\hline 7 & Encourage agriculture (1-yes; 0 -no) & $0.1241^{\star * \star}$ & 4.305 & 0.0000 \\
\hline 8 & Soil erosion mitigation ( 1 -yes; 0 -no) & $0.0593^{* *}$ & 2.197 & 0.0285 \\
\hline 9 & Shaded trees (1-yes; 0 -no) & 0.0315 & 1.190 & 0.2348 \\
\hline
\end{tabular}

(Note: ${ }^{* *}$ Significance level of $1 \%$, ${ }^{*}$ Significance level of $5 \%,{ }^{*}$ Significance level of $10 \%$ ). 


\subsubsection{For Household Coffee Yield}

$$
\mathrm{R}=0.823 ; \mathrm{R}^{2}=0.677
$$

Coefficient $R^{2}=0.677$, said independent variables in the model explained $67.7 \%$ change in the dependent variable is the coffee yield.

Through regression results show that the parameters of the model are statistically significant.

\section{The meaning of the parameters:}

Table 2 shows that parameters of coffee harvest area by 0.17003 . This is the value of the marginal productivity DTCP harvest. This value in the event that other factors in the model does not change, when the coffee harvest area increased to 1 hectare, the yields increased by 0.17003 tons/ha. This meant that households have coffee harvest area most often for higher yields.

Parameters of production capital by 0.00082 . This is the value of the marginal productivity of capital for production and trading of coffee. This value indicated, in the case of other factors in the model does not change, when the area of the coffee business capital increased to 1 million/ha, the yield of coffee increased by 0.00082 tons/ha.

Parameter of labor by 0.0028 . This is the value of the marginal productivity of labor. This value in the event that other factors in the model unchanged, rising labor to $1 /$ ha, the yield of coffee increased by 0.0028 tons/ha.

Parameters of watering method by 0.0979 said reasonable watering will give higher yields up to 0.0979 tons/ha compared with unreasonable watering.

Parameters of fertilizing method by 0.10608 said rational fertilization will give higher yields by 0.10608 tons/ha against unreasonable fertilizing.

Parameters of agricultural extension by 0.0706 , said households participate extension work will give higher yields by 0.0706 tons/ha compared to households not taking part in the agricultural extension.

Table 2. Regression results table on linear model.

\begin{tabular}{ccccc}
\hline Order & Variable & Intercept & t Stat & $P$-value \\
\hline 1 & Intercept of freedom & $0.42984^{* * *}$ & 3.000 & 0.00284 \\
2 & Coffee production area (ha) & $0.17003^{* * *}$ & 2.902 & 0.00387 \\
3 & Capital for coffee production (mil.dong) & $0.00082^{* * *}$ & 6.288 & 0.00000 \\
4 & Labor (man-day) & $0.00279^{* * *}$ & 5.103 & 0.00000 \\
5 & Irrigation methods (1-suitable; 0-unsuitable) & $0.09794^{*}$ & 1.755 & 0.07994 \\
6 & Fertilizer application(1-suitable; 0-unsuitable) & $0.10608^{* *}$ & 2.341 & 0.01962 \\
7 & Encourage agriculture (1-yes; 0-no) & $0.07063^{*}$ & 1.683 & 0.09297 \\
8 & Soil erosion mitigation (1-yes; 0-no) & $0.81658^{* * *}$ & 10.701 & 0.00000 \\
9 & Shaded trees (1-yes; 0-no) & $0.55203^{* * *}$ & 6.396 & 0.00000 \\
\hline
\end{tabular}

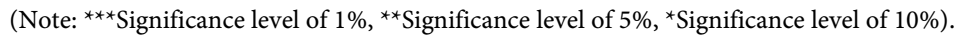


Parameters of preventing soil erosion by 0.81658 said, households have used the antierosion measures will give higher yields by 0.81658 tons/ha compared to households with no anti-erosion measures soil.

Parameters of planting windbreak trees by 0.55203 said households participate in planting windbreak trees will give higher yields by 0.55203 tons/ha compared to households with no planting windbreak trees [10].

\section{Conclusions}

In the provinces of Vietnam, the Central Highlands is considered very suitable place for growing Robusta coffee. It is planned, focusing on developing and constantly growing; coffee products have become the main export commodities of the Central Highlands province in general and Dak Lak in particular. Coffee has provided income for many households, contributing significantly to the annual GDP growth of Dak Lak province. Through analysis and evaluation in the study, results showed that the yields of the investigation group reached an average of 2.54 tons/ha. The proportion of households implemented reasonably technical measures such as fertilizing and watering is still at a low percentage (30.8\% respectively and $16.2 \%$ ). This indicates that households develop sustainable coffee but poor in techniques. Analyzing the role of water resources shows that the majority of the interviewed households responded that water resources are very important for the production of coffee and that water levels are gradually degreasing thus showing a downward trend in water levels in the future. To produce coffee business outside water source, other factors such as soil quality, coffee care techniques, capital and experience are very important factors for the sustainable development of the coffee plant. Results and business efficiency of coffee plantations of the crop year 2014/2015 reached a relatively high. Analysis of factors affecting the sustainable coffee development shows that capital, labor and soil are important factors contributing to increased yields. The implementation of effective technical measures (watering, fertilizing, soil erosion control, planting tree windbreaks), as well the agricultural extension will contribute to increase coffee productivity.

Due to poor transportation, data collection is very difficult. Therefore, the scope of this research was limited to the Dak Lak Province, a relatively small province in Vietnam. Authors wished if condition possible, the research will expand to the entire Central Highland of Vietnam-Where climatic condition and land suitable for coffee cultivation in the future. This is a limitation of the research.

The impact assessments of certain factors, such as agricultural equipment, knowledge of farmers, and the investment of capital, are essential for researching sustainable coffee development. Furthermore, the research results will provide some useful information for those working in the agricultural sector management, the agricultural extension center, and the coffee-growing households in investing, planning and development of Dak Lak coffee to reach high yielding, stable and more efficient in the future.

\section{References}

[1] Dinh, P.V. and Chung, D.K. (1997) Agricultural Economics. Hanoi Agriculture Publisher. 
[2] Specification and Estimation of Cobb-Douglas Production Function Model. http://xueshu.baidu.com/s?wd=paperuri\%3A\%28c197126fc9f01d09fb0f7a7cbcd8843b\%29\&fi lter=sc_long_sign\&tn=SE_xueshusource_2kduw22v\&sc_vurl=http\%3A\%2F\%2Fwww.jstor. org\%2Fstable\%2F1910099\&ie=utf-8\&sc_us=9327089445902437480

[3] Nhan, D.T., Tiem, H.T. and Sung, P.Q. (1999) Coffee Plant in Vietnam. Hanoi Agriculture Publisher.

[4] Dak Lak Statistical Office, Statistical Yearbook of Dak Lak, 2014, 2015.

[5] Khanh, T.Q. (2005) Agriculture Business Administration Curriculum. Hanoi Labor-Society Publisher.

[6] Binh, V.T. and Huan, D.D. (2007) Geographical Indications and Application Potential in Vietnam's Coffee Sector. Rural Development Centre, Institute of Policy and Strategy for Agriculture and Rural Development, Hanoi.

[7] Chi, T.T.Q., et al. (2007) Profile Vietnam's Coffee Industry. The Institute of Policy and Strategy for Agriculture and Rural Development, Hanoi.

[8] Thuong, N.V. (2005) Turn of the State of Demand-Supply of Coffee and the Appearance of the Coffee Markets in the World. Information Sciences and Engineering Agriculture and Forestry, 2.

[9] Herrick, B. and Kindleberger, C.P. (1988) Economic Development. 4th Edition, McGrawHill International Edition.

[10] (1987) Brundland Report, Our Common Future, World Commission on Environment and Development. Oxford University Press, Oxford. 


\section{Appendix}

Table A1. Method of fertilizing and watering of the household: role, ability and tend to provide irrigation water for coffee of households (Role of water: 1-The most important. The ability of water: 1-richest).

\begin{tabular}{|c|c|c|c|c|c|c|c|c|c|c|}
\hline Districts & \multicolumn{2}{|c|}{$\begin{array}{l}\text { Fertilization } \\
\text { method }\end{array}$} & \multicolumn{2}{|c|}{$\begin{array}{l}\text { Irrigation } \\
\text { methods (\%) }\end{array}$} & $\begin{array}{c}\begin{array}{c}\text { The role } \\
\text { of water }\end{array} \\
\text { (1 - } 4 \text { points) } \\
\text { Reasonable }\end{array}$ & $\begin{array}{c}\begin{array}{c}\text { The ability } \\
\text { of water } \\
(1-5 \text { point })\end{array} \\
\text { Not reasonable }\end{array}$ & \multicolumn{4}{|c|}{$\begin{array}{c}\text { Trends in coffee } \\
\text { irrigation water (household) }\end{array}$} \\
\hline Buôn Hồ & 12.31 & 87.69 & 12.31 & 87.69 & 1.52 & 2.95 & 0 & 3 & 23 & 39 \\
\hline Krông Ana & 15.00 & 85.00 & 15.00 & 85.00 & 1.35 & 2.73 & 0 & 1 & 8 & 31 \\
\hline Krông Bông & 12.00 & 88.00 & 12.00 & 88.00 & 1.36 & 2.36 & 0 & 1 & 6 & 18 \\
\hline Krông Búk & 47.78 & 52.22 & 47.78 & 52.22 & 1.59 & 3.17 & 0 & 4 & 25 & 61 \\
\hline Krông Pắk & 25.88 & 74.12 & 25.88 & 74.12 & 1.47 & 2.66 & 0 & 7 & 16 & 62 \\
\hline Lắk & 4.00 & 96.00 & 4.00 & 96.00 & 1.44 & 2.96 & 0 & 0 & 6 & 19 \\
\hline
\end{tabular}

Source: Survey data of the author in 2015.

Table A2. Results and coffee production efficiency of households. Unit: million/ha; Time.

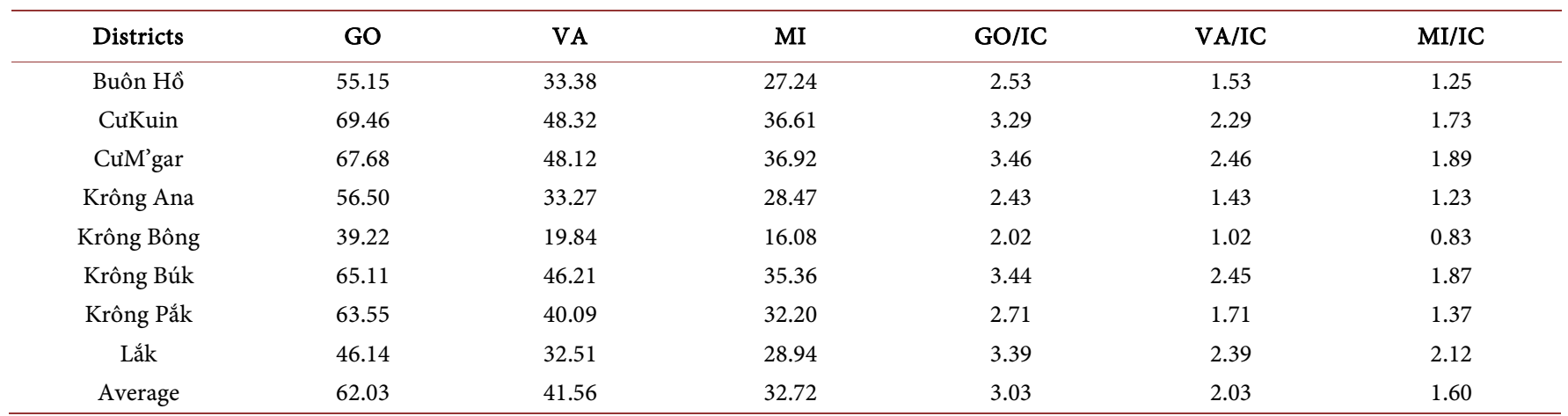

Source: Survey data of the author in 2015.

Table A3. Household evaluation of the importance level of some elements related to coffee production (for points $1-5$; 5 points is the most important).

\begin{tabular}{|c|c|c|c|c|c|c|c|c|c|}
\hline Districts & $\begin{array}{l}\text { Cultivation } \\
\text { experience }\end{array}$ & $\begin{array}{c}\text { The distance } \\
\text { and the } \\
\text { quality of roads }\end{array}$ & $\begin{array}{l}\text { Capital } \\
\text { Scale }\end{array}$ & $\begin{array}{l}\text { Area } \\
\text { Scale }\end{array}$ & $\begin{array}{c}\text { Coffee caring } \\
\text { techniques }\end{array}$ & $\begin{array}{c}\text { Soil } \\
\text { quality }\end{array}$ & $\begin{array}{c}\text { Coffee } \\
\text { area planning }\end{array}$ & $\begin{array}{c}\text { Coffee } \\
\text { consumption } \\
\text { market }\end{array}$ & $\begin{array}{c}\text { Market price } \\
\text { information }\end{array}$ \\
\hline Buôn Hồ & 3.35 & 2.15 & 3.06 & 2.75 & 2.72 & 2.82 & 2.25 & 2.38 & 2.28 \\
\hline CưKuin & 3.23 & 1.96 & 3.29 & 2.86 & 3.36 & 3.30 & 2.49 & 2.73 & 2.46 \\
\hline CưM'gar & 3.45 & 2.19 & 3.11 & 3.06 & 3.36 & 3.15 & 2.31 & 2.31 & 2.15 \\
\hline Krông Ana & 3.18 & 2.05 & 2.93 & 2.93 & 3.05 & 2.95 & 2.00 & 2.23 & 2.53 \\
\hline Krông Bông & 2.52 & 2.28 & 3.12 & 2.68 & 2.60 & 3.16 & 2.72 & 2.64 & 2.44 \\
\hline Krông Búk & 3.19 & 2.04 & 2.90 & 3.29 & 2.84 & 2.89 & 2.34 & 2.51 & 2.59 \\
\hline Krông Pắk & 3.34 & 2.15 & 3.06 & 2.80 & 2.98 & 3.06 & 2.27 & 2.47 & 2.51 \\
\hline Lắk & 2.88 & 2.04 & 3.28 & 3.08 & 2.72 & 2.48 & 2.08 & 2.68 & 2.84 \\
\hline Average & 3.24 & 2.11 & 3.08 & 2.96 & 3.02 & 3.02 & 2.31 & 2.47 & 2.43 \\
\hline
\end{tabular}


Table A4. Household coffee efficiency.

\begin{tabular}{|c|c|c|c|c|c|c|c|c|}
\hline Districts & Total coffee area & $\begin{array}{l}\text { Average output } \\
\text { (ton/ha) }\end{array}$ & \multicolumn{2}{|c|}{$<1.5$ ton/ha } & \multicolumn{2}{|c|}{$1.5-3$ ton/ha } & \multicolumn{2}{|c|}{$>3$ ton $/$ ha } \\
\hline Buôn Hồ & 65.70 & 2.29 & 12.70 & 19.33 & 11.80 & 17.96 & 41.20 & 62.71 \\
\hline CưKuin & 68.20 & 2.80 & 0.00 & 0.00 & 24.20 & 35.48 & 44.00 & 64.52 \\
\hline CưM'gar & 118.60 & 2.74 & 5.60 & 4.72 & 35.90 & 30.27 & 77.10 & 65.01 \\
\hline Krông Bông & 21.60 & 1.67 & 9.00 & 41.67 & 0.40 & 1.85 & 12.20 & 56.48 \\
\hline Krông Búk & 110.10 & 2.65 & 6.00 & 5.45 & 34.20 & 31.06 & 69.90 & 63.49 \\
\hline Krông Păk & 90.44 & 2.61 & 9.50 & 10.50 & 31.10 & 34.39 & 49.84 & 55.11 \\
\hline Lắk & 30.12 & 1.95 & 5.10 & 16.93 & 3.60 & 11.95 & 21.42 & 71.12 \\
\hline
\end{tabular}

Source: Survey data of the author in 2015.

Submit or recommend next manuscript to OALib Journal and we will provide best service for you:

- Publication frequency: Monthly

- 9 subject areas of science, technology and medicine

- Fair and rigorous peer-review system

- Fast publication process

- Article promotion in various social networking sites (LinkedIn, Facebook, Twitter, etc.)

- Maximum dissemination of your research work

Submit Your Paper Online: Click Here to Submit

Or Contact service@oalib.com 